\title{
A reference map of human nasopharyngeal squamous carcinoma proteome
}

\author{
FENG LI $^{1,2^{*}}$, ZHIQIANG XIAO ${ }^{1 *}$, PENGFEI ZHANG $^{1},{\text { JIANLING } I^{2}, \text { MAOYU LI }}^{1}$, \\ XUEPING FENG ${ }^{1}$, YONGJUN GUAN ${ }^{2}$ and ZHUCHU CHEN ${ }^{1,2}$ \\ ${ }^{1}$ Key Laboratory of Cancer Proteomics of Chinese Ministry of Health, Xiangya Hospital \\ and ${ }^{2}$ Cancer Research Institute, Central South University, Changsha, P.R. China
}

Received September 18, 2006; Accepted November 27, 2006

\begin{abstract}
In order to conduct a comparative proteomics study of human nasopharyngeal carcinoma (NPC) to understand the molecular mechanisms that participate in the formation of NPC, the two-dimensional gel electrophoresis (2-DE) reference map of human NPC tissue proteome was described. To provide a high level of reproducibility between gels and accurately array each protein expressed in NPC tissue proteome, the two-dimensional polyacrylamide gel electrophoresis system, modified colloidal Coomassie Brilliant Blue staining method and ImageMaster 2D Platinum image analysis software were used. The NPC 2-DE maps show that high quality and good reproducibility of the 2-DE gel pattern was attained. An average total of 1,100 protein spots were separated by $2-\mathrm{DE}$, visualized by a modified colloidal Coomassie Brilliant Blue staining method. A synthesized 2-DE reference gel was acquired after detailed analysis of the NPC 2-DE gel maps, and 216 medium to high abundant spots were identified as landmark spots of NPC 2-DE gel, which expressed on $>75 \%$ of gels. To provide an unambiguous identification of the landmark spots in gels, MALDI-TOF, ESI-Q-TOF mass spectrometry and database search were used to identify the proteins expressed in NPC tissue proteome. Between the 216 landmark spots, all proteins were identified with MALDI-TOF at first, 41 of which were identified with both MALDI-TOF and ESI-Q-TOF. All identified proteins were classified in terms of their subcellular localization and physiological function with information from SWISS-PROT and NCBI websites. According to our knowledge this is the first 2-DE reference map of human NPC. This reference map will serve as a basis for further studies of
\end{abstract}

Correspondence to: Dr Zhuchu Chen, Key Laboratory of Cancer Proteomics of Chinese Ministry of Health, Xiangya Hospital, Cancer Research Institute, Central South University, \#87 Xiangya Road, Changsha 410078, P.R. China

E-mail: tcbl@xysm.net

*Contributed equally

Abbreviations: NPC, nasopharyngeal carcinoma; CHCA, $\alpha$-cyano4-hydroxycinnamic acid; PMF, peptide mass fingerprint

Key words: nasopharyngeal carcinoma, proteome, reference map, two-dimensional gel electrophoresis, mass spectrometry human NPC and the reference map data will be used to expand the proteome database of human NPC, which can be accessed in our website http://www.xyproteomics.org/.

\section{Introduction}

Nasopharyngeal carcinoma (NPC) is one of the most common cancers in southern China and Southeast Asia. This cancer is prevalent in the southern part of China including Guangdong and Hunan Provinces $(25-50 / 100,000)$ but less so among northern Chinese $(3 / 100,000)$. Moreover, the Cantonese are the most frequently affected population and have an incidence rate of NPC nearly 100-fold higher than that seen in Caucasians. The marked geographic and racial differences in incidence of NPC indicate that the development of this cancer must be related to special genetic and environmental factors (1-3).

Molecular genetic studies have indicated that inactivation of tumor suppressor genes on 3p, 9p, 11q, 13q, 14q and 16q and alterations of oncogenes on chromosomes 8 and 12 are important in the pathogenesis of NPC. LOH studies also suggested that multiple tumor suppressor loci at 3p13-14.3, 3 p21, and 3p21-25 were involved (4-6). In addition to genetic alteration, Epstein-Barr virus (EBV) latent infection plays an important role in pathogenesis of NPC. The detection of a single form of viral DNA in NPC cells suggests that the tumors are clonal proliferations of a single cell that was initially infected with EBV. Environmental factors including traditional diets and early exposure to salted fish have also been reported to be high risk factors with nasopharyngeal carcinoma (7-9).

However, these research topics of NPC mainly focused on a minority of interesting proteins and genes. As we all know, NPC carcinogenesis is a result of complex interaction processes of multiple genes, multiple proteins and multiple factors. The study of a minority of several proteins or genes will not be sufficient to understand the pathogenesis of NPC in a global eye (10). Therefore, a global analysis system such as proteomics is needed to analyze all parameters as far as possible that might participate in the pathogenesis of NPC (10-12).

Proteomics mapping of tissue and cell proteins is the preferred method for investigating the pathogenesis of human NPC. The differentially expressed proteins can be identified through comparing the 2-DE reference gels representing the typical pattern of human NPC with normal nasopharyngeal 
epithelia. Because differentially expressed spots among the matched 2-DE gels can be varied especially when there are some inconstant differentially expressed spots, many samples are needed to confirm their validity. On the other hand, the differentially expressed spots may be artifacts that are introduced by gel warping. Thus, in order to conduct a confirmed comparative proteomics study of the NPC, a reference map of NPC proteome is needed. Several 2-DE reference maps are now available on the ExPASy website, including maps of various microorganisms and also those of human organs, cells, and fluids, as well as those of several cell lines $(13,14)$. To our knowledge, no detailed 2-DE reference map of human NPC is currently available. To fill this gap, we constructed a 2-DE reference map of human NPC. In our laboratory, the experimental conditions and reproducibility of 2-DE have been optimized (15), and it was used in this study. A modified colloidal Coomassie Brilliant Blue staining method, which was so called Blue Silver staining, was used to visualize more protein spots in the 2-DE gels and improve compatibility with mass spectrometry (16). MALDI-TOF MS and ESIQ-TOF tandem mass spectrometry were used at the same time to validate each other and acquire unambiguous protein identification.

On the 2-DE reference gel of human NPC we identified 216 distinct spots. The data are presented in terms of the different functional classes of proteins and their relevance to the NPC proteome. The 2-DE reference map of human NPC will offer a basis for research involved in NPC, and open the way to investigate the NPC protein changes associated with NPC pathogenesis.

\section{Materials and methods}

Instruments and software. IPGphor, Ettan DALT II System, ImageScanner (maximum resolution 9600*9600 dpi), ImageMaster 2D Platinum analysis software (Amersham Pharmacia Biotech, USA), Centrifuge (Eppendorf, Germany), Voyager-DE STR MALDI-TOF Mass Spectrometry (AppliedBiosystems, USA), ESI-Q-TOF Mass Spectrometry (Micromass, UK), Mascot Distiller and Mascot Database Search engine and Statistical Package For Social Science (SPSS for windows, version 10.01, USA) were used.

Reagent. Immobiline pH-gradient DryStrips (pH 3-10L, $24 \mathrm{~cm}$ ), IPG buffer (pH 3-10), DryStrip cover fluids, thiourea, urea, CHAPS, dithiothreitol, Pharmalyte ( $\mathrm{pH} 3-10)$, bromophenol blue, acrylamide/bis-acrylamide (29:1 = w: $)$, TEMED, low-molecular-weight marker, Tris-base, SDS and glycine were purchased from Amersham Pharmacia Biotech. Mercaptoethanol, iodoacetamide, $\mathrm{HCl}$, Coomassie Brilliant Blue G-250, and 37\% v/v formaldehyde were from Sigma. Acetic acid, glycerol, methanol, sodium thiosulfate, and sodium carbonate were from Fisher. PAGE (12\%) resolving gel was cast with a DALT II Gel Caster. All buffers were prepared with Milli-Q water.

Tissue samples (preparation of tissue proteins). Twenty fresh nasopharyngeal carcinoma biopsy specimens were obtained from Xiangya Hospital, Central South University, Hunan Province, P.R. China, and were diagnosed by pathology. These specimens were immediately frozen in liquid nitrogen after excision and flushing out of blood and then stored at $-80^{\circ} \mathrm{C}$ until analysis. The tissue specimens of low-differentiated squamous cell carcinoma were selected in this study. Five tissue specimens were randomly put into a pool and a total of $85 \mathrm{mg}$ nasopharyngeal tissues were ground into powder in liquid nitrogen and lysed in $400 \mu 1$ lysis buffer $(7 \mathrm{~mol} / 1$ urea, $2 \mathrm{~mol} / \mathrm{l}$ thiourea, $100 \mathrm{mM} / \mathrm{l} \mathrm{DTT}, 4 \%$ CHAPS, $40 \mathrm{mM} / \mathrm{l}$ Tris, $2 \%$ pharmalyte, $1 \mathrm{mg} / \mathrm{ml}$ DNase I). The lysates were incubated at $4^{\circ} \mathrm{C}$ for $1 \mathrm{~h}$ and centrifuged at 15,000 rpm for 45 $\min$ at $4^{\circ} \mathrm{C}$. The super-natant was transferred to a fresh tube and stored at $-80^{\circ} \mathrm{C}$ until use. The concentration of the total proteins was determined with the 2D Quantification kit (Amersham Biosciences).

2-DE. 2-DE was performed as described by the manufacturer (Amersham Biosciences) and Görg et al (17). Protein samples (800 $\mu \mathrm{g}$ for preparative gels) were mixed with loading buffer for IPG strips to obtain a final volume of $450 \mu 1$. Firstdimension IEF was performed using IPGstrip (pH 3-10L, $240 \mathrm{~mm} \times 3 \mathrm{~mm}$ x $0.5 \mathrm{~mm}$ ) on an IPGphor isoelectric focusing cell. In the reswelling step of dry IPG strips, $30 \mathrm{v}$ was applied at the same time. Second-dimension SDS-PAGE was performed on an Ettan DALT II system. After electrophoresis, the Blue Silver staining method was used to visualize the protein spots in the 2-DE gels.

Image analysis. The stained 2-DE gels were scanned with MagicScan software on Imagescanner. ImageMaster 2D Platinum analysis software was used for spot intensity calibration, spot detection, background subtraction, and 1-D calibration. After matching analysis of the NPC 2-DE gel maps, a synthesized NPC 2-DE reference gel was acquired. The relative volume $(\% \mathrm{Vol})$ of each spot was quantified by calculation of spot volume after normalization of the image using the total spot volume normalization method multiplied by 100 . Two hundred and sixteen spots with medium to high relative volume and expressed on $>75 \%$ gels were identified as landmark spots of the NPC 2-DE synthesized reference gel. The reproducibility of the spot position was calculated with Gorbett's method (18). Statistical analysis was carried out with SPSS for Windows 10.0 and Excel.

Protein identification. Landmark spots were excised from preparative gels using punch and transferred into a $1.5-\mathrm{ml}$ siliconized Eppendorf tube. One protein-free gel piece was treated in parallel as a negative control. Proteins were in-gel digested as previously described. The gel-pieces were destained according to the EMBL Bioanalytical Research Group's in-gel digestion protocol. The dried gel-pieces were incubated in $10 \mu \mathrm{l}$ digestion solution consisting of $40 \mathrm{mM} / \mathrm{NH}_{4} \mathrm{HCO}_{3}$ in $9 \%$ acetonitrile solution and $20 \mu \mathrm{g} / \mathrm{ml}$ proteomics grade trypsin for $10-12 \mathrm{~h}$ at $37^{\circ} \mathrm{C}$. The tryptic peptide mixture was extracted and purified with a Millipore ZipTipC (18) column.

The samples were analyzed with a MALDI-TOF Mass Spectrometer (ABI) or ESI-Q-TOF mass spectrometry (Micromass). The purified tryptic peptide mixture was mixed with CCA matrix solution and vortexed gently. A volume $(1 \mu 1)$ of the mixture containing CCA matrix was loaded on a stainless steel plate and air-dried. The standard peptide mixture 
was spotted at the same time to correct the machine. The parameters of MALDI-TOF were set up as follows: positive ion-reflector mode, $20-\mathrm{kV}$ accelerating voltage, $64.5 \%$ grid voltage, 1.12 mirror voltage ratio, 337- $\mathrm{nm} \mathrm{N}_{2}$ laser wavelength, 3 -ns pulse width, 50 laser shots, 800 - to 3000 -Da acquisition mass range, $100-n s$ delay, and $4 \times 10^{-7}$ Torr vacuum degree.

Some mass spectra were obtained on an ESI-Q-TOF mass spectrometry fitted with a nanoelectrospray ionization source. For on-line LC/MS analysis, a Waters CapLC solvent delivery system was coupled to the mass spectrometry. The samples were loaded to a pre-column $[320 \mu \mathrm{m}$ x $50 \mathrm{~mm}$, $5 \mu \mathrm{mC}$ (18) silica beads, Waters] at $30 \mu \mathrm{l} / \mathrm{min}$ flow rates for concentrations and fast desalting through a Waters CapLC Autosampler, then eluted to the reversed phase column (75 $\mu \mathrm{m} \times 150 \mathrm{~mm}, 5 \mu \mathrm{m}, 100 \mathrm{~A}$, LC Packing) at a flow rate of $200 \mathrm{nl} / \mathrm{min}$ after flow splitting for separation. MS/MS spectra were performed in data-depended mode in which up to 4 precursor ions above an intensity threshold ( 7 counts/ sec, cps) were selected for MS/MS analysis from each survey 'scan'. The nanoelectrospray parameters were 3,000 V for capillary voltage, $45 \mathrm{~V}$ for cone voltage, $80^{\circ} \mathrm{C}$ for source temperature and 15 psi collision gas back pressure.

Database analysis. In peptide mass fingerprint (PMF) map database searching, Mascot Distiller was used to get the monoisotopic peak list from the raw mass spectrometry files. The monoisotopic peak list was used to search the MSDB or NCBInr database with the Mascot search engine (http://www. matrixscience.com/). The searching parameters were set up as follows: the taxonomy was selected as all entries or Homo sapiens; the mass tolerance was \pm 200 ppm; missed cleavage sites were allowed up to 1 ; fixed modifications were selected as carboxymethyl (cysteine); the variable modification was selected as Oxidation (methylation) or none.

In tandem mass spectrometry data database query, the PKL format file that was generated from MS/MS mass spectrometry was imported into the Mascot search engine. The searching parameters were set up as follows: the taxonomy was selected as all entries or Homo sapiens; the mass tolerance was $\pm 1.0 \mathrm{Da}$; the MS/MS tolerance was $\pm 0.5 \mathrm{Da}$; missed cleavage sites were allowed up to 1 ; fixed modifications were selected as carboxymethyl (cysteine); the variable modification was selected as Oxidation (methylation) or none; the data format was selected as Micromass PKL format and the Instrument was selected as ESI-QUAD-TOF.

\section{Results and discussion}

Protein preparation and separation. In NPC histological pathology, $>95 \%$ of NPC belong to low differentiated nasopharyngeal squamous cell carcinoma or non-differentiated squamous cell carcinoma. The high malignancy of NPC results in tumors increasing rapidly and metastasizing at the early stage, and $>75 \%$ of patients were at stage III or IV when diagnosed (2). Because of the importance of low differentiated nasopharyngeal squamous cell carcinoma in NPC, all the cases used in this study were diagnosed by pathology to be low differentiated nasopharyngeal carcinoma. Due to the especially anatomic localization and biological feature of NPC, the weight of NPC biopsy tissues usually will be no higher than $20 \mathrm{mg}$, so it is very important to recover NPC tissue powers from mortar as much as possible and increase protein extraction efficiency at the same time. To improve the protein solubility of the NPC tissue sample, chemical and physical methods were combined to process the tissues and extract proteins. Based on our previous protocol, some modifications have been made here: to improve protein solubilization, a combination of urea and thiourea was used, and pharmalyte was added to protein solubilization buffer; to remove any indissoluble material before IEF, sufficient time centrifugation $\left(45 \mathrm{~min} \times 15,000 \mathrm{x} \mathrm{g}, 4^{\circ} \mathrm{C}\right.$ ) was used.

For the 2-DE system, a 24-cm IPGstrip combined with the vertical multigel electrophoresis system was used in this study. More protein spots can be separated by a $24-\mathrm{cm} \mathrm{pH} \mathrm{3-}$ 10L IPGstrip than other IPGstrips because of its length. The vertical multigel electrophoresis system, which can analyze up to 12 gels at a time, can provide a higher reproducibility between 2-DE gels. 2-DE gel patterns of a human NPC proteome with high-resolution and high-reproducibility were attained (Fig. 1). An average total of 1,100 protein spots were detected in the 2-DE map shown in Fig. 1 and the average positional deviation of the matched-spots among four replicate 2-DE gels of one pool was $1.55 \pm 0.35 \mathrm{~mm}$ in the IEF direction, and $1.78 \pm 0.55 \mathrm{~mm}$ in the SDS-PAGE direction according to Gorbett's calculating method (data not shown).

2-DE map of human nasopharyngeal squamous carcinoma. To reliably identify the differentially expressed proteins in the two-dimensional difference gel electrophoresis, the landmark spots in the 2-DE gel reference maps would be very helpful for the following reasons: a) when the difference spots were low expressed proteins, it was difficult to identify them without the aims of landmark spots; b) at the current 2-DE technology condition gel distortion was difficult to fully discover, which increased the difficulty of image analysis and the need for landmark spots to correct gel distortion; c) the 2-DE image analysis software was not ideal for spot detection or gelmatching, most of the software still needed human eyes to find the matched landmark spots; d) the 2-DE maps would be insufficient for image analysis when the analyzed samples are very complex; and e) the 2-DE gel reference map provided some useful composition information of the analyzed cells. One study showed that even housekeeping proteins such as GAPDH, $\beta$-actin and $\beta$-tubulin varied much between a number of different established renal cancer cell lines, matched pairs of renal tumor and normal kidney lysates as well as nine different human tissues (19). Thus, a good 2-DE reference map of human nasopharyngeal squamous carcinoma with many landmark spots is essential for a reliable comparative proteomics study of different differentiated degrees of nasopharyngeal squamous carcinoma, NPC and normal nasopharyngeal epithelia. In the 2-DE maps shown in Fig. 1, Blue Silver, a modified method of colloidal Coomassie Brilliant Blue staining was used to attain the high quality NPC 2-DE gel maps, and an average of 1,100 protein spots of every gel were detected through this modified staining method by 2-DE gel analysis software ImageMaster 2D Platinum. The green box region was magnified and red arrays showed the matched landmark spots in this region. In Fig. 2, 216 spots highly expressed in $75 \%$ of gels and identified as landmark spots in 


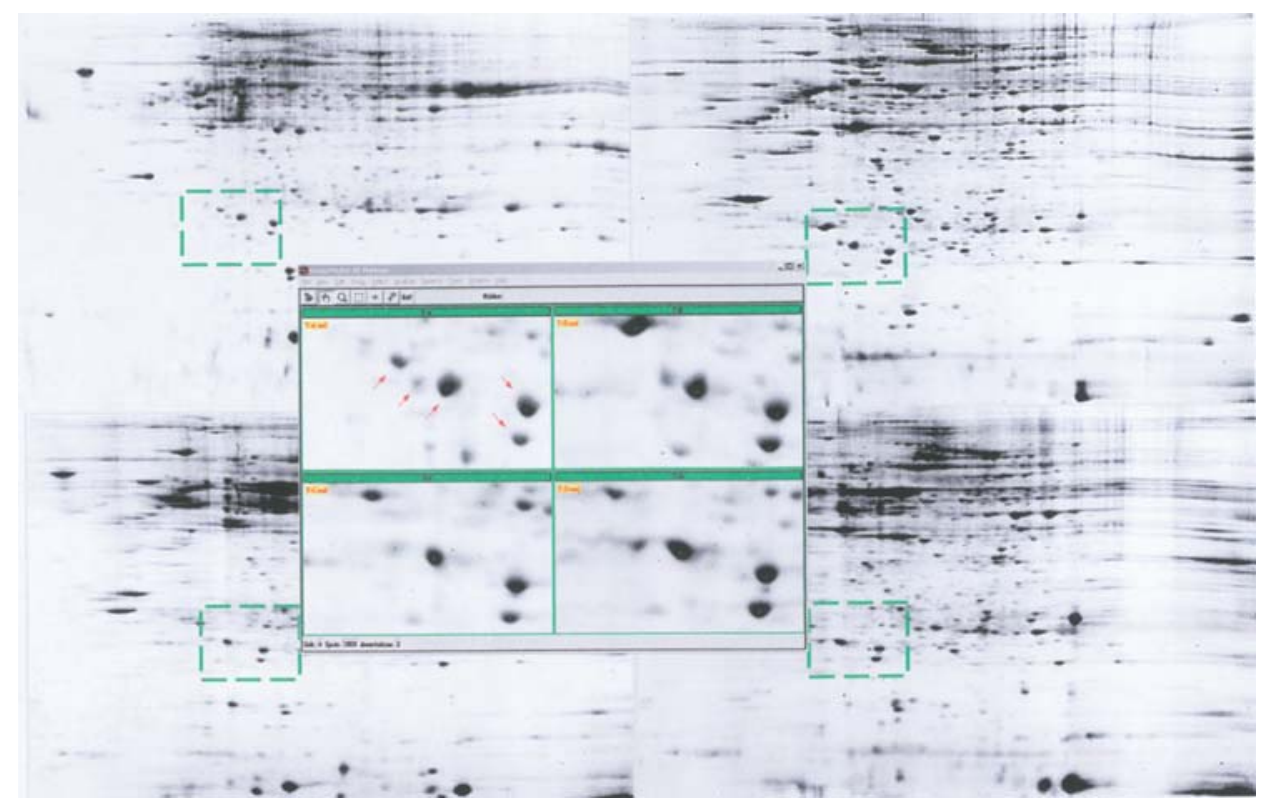

Figure 1. The 2-DE gel maps of NPC and matched landmark spots.

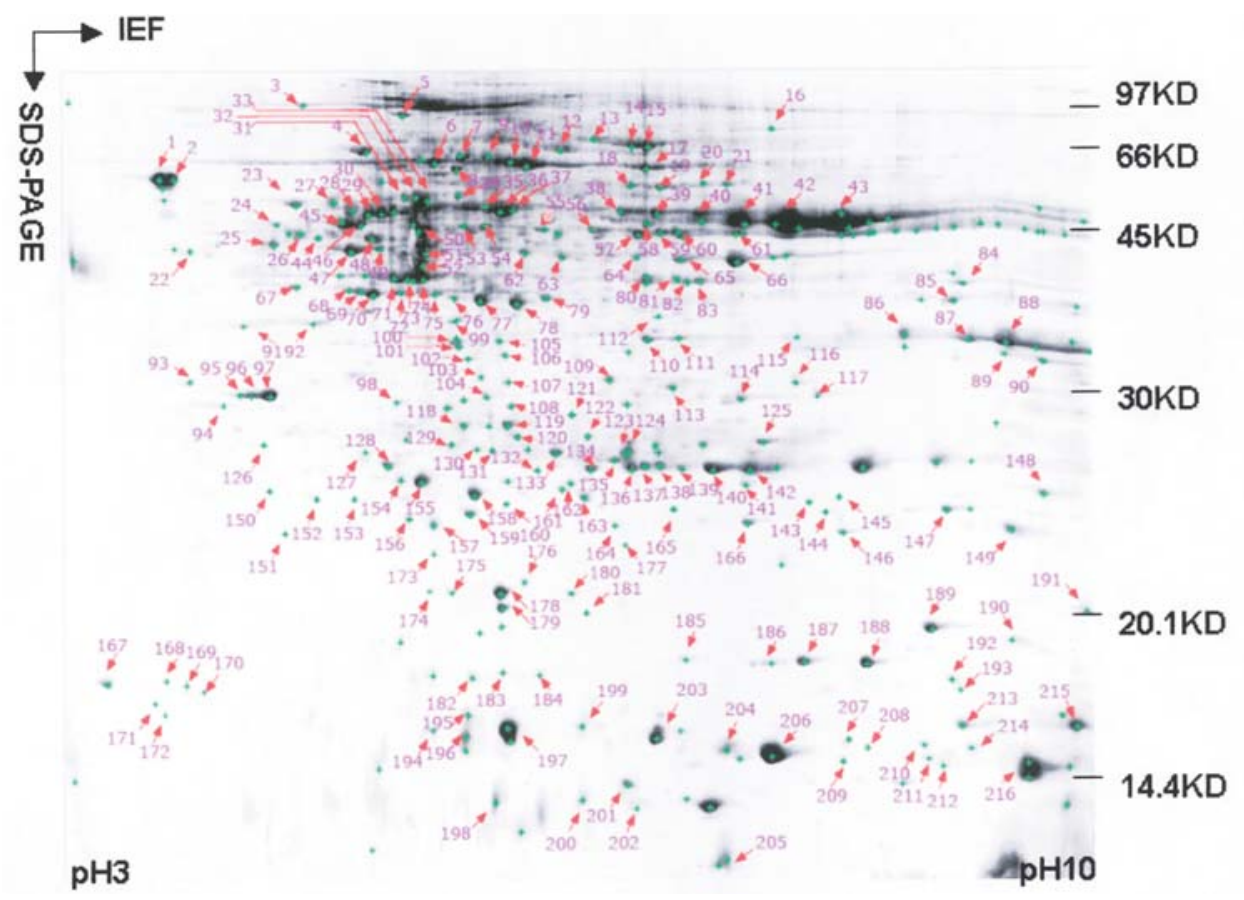

Figure 2. The synthetic 2-DE reference gel map of NPC.

the reference gel were marked with a purple number and red arrow, respectively, in the center of the spots a green plus symbol was added automatically by ImageMaster 2D Platinum.

Undoubtedly, silver staining is a more sensitive staining method than Coomassie Brilliant Blue staining as it can visualize more spots in 2-DE gels, but this method also has problems: first, the linear consistency of protein spot quantity with protein spot volume is not as good as with Coomassie Brilliant Blue staining, so many differential proteome analyses prefer classical organic dyes of the Coomassie family or use fluorescence dye; second, the compatibility of mass spectrometry is not as good as Coomassie Brilliant Blue staining, which will greatly affect the successful identification of the protein spots of the gels, especially low abundance protein spots. Blue Silver, a modification method of colloidal Coomassie Brilliant Blue with a sensitivity close to silver staining and the advantage of linear consistency and mass spectrometry compatibility should be the right choice in 2-DE gel staining.

Protein identification by MS. All spots were identified by MALDI-TOF PMF at first, 41 spots among these spots were identified by MALDI-TOF PMF and ESI-Q-TOF tandem MS/MS simultaneously. The detailed information of identified proteins is listed in Table I, which can also be accessed from 
Table I. Detailed information about the identified proteins.

\begin{tabular}{|c|c|c|c|c|c|c|c|c|c|}
\hline $\begin{array}{l}\text { Spot } \\
\text { ID }\end{array}$ & Protein name & $\mathrm{AC}$ & pI & MW & Score & $\begin{array}{l}\text { Coverage } \\
(\%)\end{array}$ & $\mathrm{M} / \mathrm{Q}$ & Localization & Function \\
\hline 1 & Calreticulin & gil30583735 & 4.29 & 48283 & 188 & 57 & $17 / 48$ & Membrane & Protein process \\
\hline 2 & Calreticulin & gil30583735 & 4.29 & 48283 & 182 & 55 & $17 / 51$ & Membrane & Protein process \\
\hline 3 & Transferrin & gil37747855 & 6.97 & 79310 & 218 & 31 & $20 / 32$ & Extracellular & Transport \\
\hline 4 & $\mathrm{BiP}$ protein & gil6470150 & 5.23 & 71002 & 270 & 50 & $34 / 69$ & Membrane & Energy \\
\hline 5 & $\begin{array}{l}\text { Valosin containing } \\
\text { protein }\end{array}$ & gil30023842 & 5.14 & 89950 & 105 & 21 & $14 / 35$ & Membrane & Energy \\
\hline 6 & $\begin{array}{l}\text { Heat shock } 70 \mathrm{kDa} \\
\text { protein } 9 \mathrm{~B} \text { precursor }\end{array}$ & gil12653415 & 6.03 & 73967 & 83 & 40 & $21 / 60$ & Cytoplasm & Cell death/defense \\
\hline 7 & $\begin{array}{l}\text { Heat shock } 70 \mathrm{kDa} \\
\text { protein } 1 \mathrm{~B}\end{array}$ & gil4885431 & 5.48 & 70267 & 191 & 51 & $24 / 57$ & Cytoplasm & Cell death/defense \\
\hline 8 & Serum albumin & gil3212456 & 5.62 & 68425 & 293 & 56 & $32 / 58$ & Plasma & Other \\
\hline 9 & Serum albumin & gil3212456 & 5.62 & 68425 & 290 & 56 & $31 / 57$ & Plasma & Other \\
\hline 10 & Serum albumin & gil3212456 & 5.62 & 68425 & 290 & 56 & $31 / 57$ & Plasma & Other \\
\hline 11 & Serum albumin & gil3212456 & 5.62 & 68425 & 290 & 56 & $31 / 67$ & Plasma & Other \\
\hline 12 & Serum albumin & gil52001697 & 5.63 & 67690 & 104 & 27 & $13 / 32$ & Plasma & Other \\
\hline 13 & PRO1400 & gil6650772 & 6.95 & 65304 & 105 & 30 & $14 / 49$ & Plasma & Transport \\
\hline 14 & Transferrin & gil37747855 & 6.97 & 79310 & 326 & 52 & $34 / 55$ & Extracellular & Transport \\
\hline 15 & PRO1400 & gil6650772 & 6.95 & 65304 & 163 & 40 & $20 / 47$ & Plasma & Transport \\
\hline 16 & Aconitase 2 & gil47678261 & 7.36 & 86113 & 242 & 33 & $20 / 28$ & Mitochondria & Metabolism \\
\hline 17 & Serum albumin & gil55669910 & 5.57 & 67174 & 320 & 57 & $31 / 60$ & Plasma & Other \\
\hline 18 & Serum albumin & gil55669910 & 5.57 & 67174 & 320 & 57 & $31 / 60$ & Plasma & Other \\
\hline 19 & $\begin{array}{l}\text { Stress-induced- } \\
\text { phosphoprotein } 1\end{array}$ & gil5803181 & 6.17 & 63227 & 183 & 52 & $23 / 43$ & Cytoplasm & Cell death/defense \\
\hline 20 & $\alpha 1$ antitrypsin & gil1942629 & 5.37 & 44280 & 89 & 26 & $8 / 22$ & Extracellular & Cell death/defense \\
\hline 21 & $\begin{array}{l}\text { Heterogeneous nuclear } \\
\text { ribonucleoprotein L }\end{array}$ & gil133274 & 6.65 & 60719 & 69 & 18 & $9 / 38$ & Nucleus & Signal cell death \\
\hline 22 & $\alpha 1$ antitrypsin & gil1942629 & 5.37 & 44280 & 82 & 37 & $9 / 30$ & Extracellular & Cell death/defense \\
\hline 23 & $\begin{array}{l}\text { Prolyl 4-hydroxylase, } \\
\text { ß subunit }\end{array}$ & gil20070125 & 4.76 & 57480 & 173 & 40 & $20 / 44$ & ER & Metabolism \\
\hline 24 & $\begin{array}{l}\text { Retinoblastoma } \\
\text { binding protein } 4\end{array}$ & gil15929379 & 4.8 & 40791 & 69 & 20 & $7 / 21$ & Nucleus & Signal \\
\hline 25 & Vimentin & gil340219 & 5.03 & 53738 & 107 & 36 & $17 / 58$ & Cytoskeleton & Structural \\
\hline 26 & Unnamed protein product & gil28193184 & 5.1 & 35332 & 101 & 35 & $8 / 18$ & Unknown & Unknown \\
\hline 27 & $\alpha 1$ antitrypsin & gil1942629 & 5.37 & 44280 & 115 & 31 & $10 / 28$ & Extracellular & Cell death/defense \\
\hline 28 & $\alpha 1$ antitrypsin precursor & gil1942629 & 5.37 & 44280 & 162 & 37 & $16 / 47$ & Extracellular & Cell death/defense \\
\hline 29 & $\alpha 1$ antitrypsin precursor & gil1942629 & 5.37 & 44280 & 98 & 34 & $10 / 28$ & Extracellular & Cell death/defense \\
\hline 30 & $\alpha$ tubulin 2 & gil34740335 & 4.94 & 50804 & 86 & 42 & $12 / 35$ & Cytoskeleton & Structural \\
\hline 31 & Chaperonin 60 & gil6996447 & 5.7 & 61187 & 103 & 28 & $13 / 48$ & Cytoplasm & Protein process \\
\hline 32 & Chaperonin & gil31542947 & 5.7 & 61187 & 67 & 10 & $5 / 8$ & Cytoplasm & Protein process \\
\hline 33 & Chaperonin & gil31542947 & 5.7 & 61187 & 67 & 10 & $5 / 8$ & Cytoplasm & Protein process \\
\hline 34 & $\begin{array}{l}\text { Protein for } \\
\text { IMAGE:3534054 }\end{array}$ & gil14495685 & 6.09 & 43461 & 124 & 49 & $10 / 19$ & Unknown & Unknown \\
\hline 35 & Protein disulfide-isomerase & gil7437388 & 5.98 & 57160 & 156 & 54 & $25 / 89$ & ER & Protein process \\
\hline 36 & Protein disulfide-isomerase & gil2135267 & 5.98 & 57115 & 156 & 54 & $25 / 89$ & ER & Protein process \\
\hline 37 & Protein disulfide-isomerase & gil2135267 & 5.98 & 57115 & 156 & 54 & $25 / 89$ & ER & Protein process \\
\hline 38 & Fibrin $B$ & gil223002 & 7.95 & 51358 & 180 & 62 & $23 / 75$ & Plasma & Other \\
\hline 39 & Fibrin $\beta$ & gil223002 & 7.95 & 51358 & 146 & 60 & $18 / 53$ & Plasma & Other \\
\hline 40 & Fibrinogen $B$ chain precursor & gil7924018 & 8.54 & 56577 & 146 & 41 & $16 / 49$ & Plasma & Other \\
\hline 41 & Fibrinogen $B$ chain precursor & gil7924018 & 8.54 & 56577 & 268 & 67 & $29 / 66$ & Plasma & Other \\
\hline 42 & Fibrinogen $B$ chain precursor & gil7924018 & 8.54 & 56577 & 202 & 70 & $34 / 76$ & Plasma & Other \\
\hline 43 & Fibrinogen $\beta$ chain precursor & gil7924018 & 8.54 & 56577 & 212 & 71 & $35 / 76$ & Plasma & Other \\
\hline 44 & $\alpha 1$ antitrypsin & gil1942629 & 5.37 & 44280 & 156 & 36 & $14 / 35$ & Extracellular & Cell death/defense \\
\hline 45 & Tubulin $B$ chain & gil338695 & 4.75 & 50240 & 148 & 41 & $17 / 46$ & Cytoskeleton & Structural \\
\hline
\end{tabular}


Table I. Continued.

\begin{tabular}{|c|c|c|c|c|c|c|c|c|c|}
\hline $\begin{array}{l}\text { Spot } \\
\text { ID }\end{array}$ & Protein name & $\mathrm{AC}$ & pI & MW & Score & $\begin{array}{l}\text { Coverage } \\
(\%)\end{array}$ & M/Q & Localization & Function \\
\hline 46 & Tubulin $B$ chain & gil338695 & 4.75 & 50240 & 148 & 41 & $17 / 46$ & Cytoskeleton & Structural \\
\hline 47 & Keratin 16 & gil24430192 & 4.99 & 51578 & 152 & 43 & $16 / 47$ & Cytoskeleton & Structural \\
\hline 48 & ATP synthase & gil32189394 & 5.26 & 56525 & 139 & 56 & $18 / 63$ & Mitochondria & Energy \\
\hline 49 & ATP synthase & gil32189394 & 5.26 & 56525 & 93 & 43 & $16 / 79$ & Mitochondria & Energy \\
\hline 50 & $\begin{array}{l}\text { Heterogeneous nuclear } \\
\text { ribonucleoprotein F }\end{array}$ & gil16876910 & 5.38 & 46013 & 90 & 30 & $9 / 30$ & Nucleus & Signal \\
\hline 51 & TXNDC5 protein & gil12654715 & 5.32 & 36725 & 98 & 40 & $11 / 55$ & ER & Unknown \\
\hline 52 & TXNDC5 protein & gil12654715 & 5.32 & 36725 & 108 & 45 & $14 / 63$ & ER & Unknown \\
\hline 53 & Keratin 8 & gil33875698 & 5.62 & 55787 & 181 & 28 & $15 / 22$ & Cytoskeleton & Structural \\
\hline 54 & Keratin 8 & gil4504919 & 5.62 & 53671 & 144 & 57 & $22 / 79$ & Cytoskeleton & Structural \\
\hline 55 & $\begin{array}{l}\text { Heterogeneous nuclear } \\
\text { ribonucleoprotein } \mathrm{H} 1\end{array}$ & gil48145673 & 5.79 & 49384 & 78 & 29 & $8 / 22$ & Nucleus & Signal \\
\hline 56 & Chaperonin containing TCP1 & gil5453603 & 6.01 & 57794 & 223 & 62 & $24 / 55$ & Cytoplasm & Protein process \\
\hline 57 & Fibrin $B$ & gil223002 & 7.95 & 51358 & 94 & 37 & $10 / 33$ & Plasma & Other \\
\hline 58 & Aldehyde dehydrogenase 1 & gil2183299 & 6.3 & 55427 & 87 & 29 & $10 / 29$ & Cytoplasm & Metabolism \\
\hline 59 & Cytosol aminopeptidase & gil12643394 & 6.29 & 53006 & 278 & 59 & $26 / 48$ & Cytoplasm & Structural \\
\hline 60 & Cytosol aminopeptidase & gil12643394 & 6.29 & 53006 & 189 & 38 & $18 / 50$ & Cytoplasm & Structural \\
\hline 61 & Fibrin $\beta$ & gil223002 & 7.95 & 51358 & 243 & 82 & $23 / 55$ & Plasma & Other \\
\hline 62 & $\begin{array}{l}\text { Proteasome 26SATPase } \\
\text { subunit } 2\end{array}$ & gil4506209 & 5.71 & 49002 & 130 & 53 & $21 / 85$ & $\begin{array}{l}\text { Several } \\
\text { compartments }\end{array}$ & Metabolism \\
\hline 63 & $\begin{array}{l}\text { Fragment double-D } \\
\text { from human fibrin }\end{array}$ & gil28373962 & 5.84 & 38081 & 108 & 33 & $9 / 23$ & Plasma & Other \\
\hline 64 & ENO1 protein & gil29792061 & 7.01 & 47481 & 89 & 23 & $8 / 20$ & Cytoplasm & Metabolism \\
\hline 65 & ENO1 protein & gil29792061 & 7.01 & 47481 & 151 & 50 & $18 / 50$ & Cytoplasm & Metabolism \\
\hline 66 & ENO1 protein & gil29792061 & 7.01 & 47481 & 157 & 51 & $14 / 29$ & Cytoplasm & Metabolism \\
\hline 67 & Keratin 19 & gil1070608 & 5.11 & 44065 & 331 & 78 & $29 / 50$ & Cytoskeleton & Structural \\
\hline 68 & Keratin 19 & gil1070608 & 5.11 & 44065 & 331 & 78 & $29 / 50$ & Cytoskeleton & Structural \\
\hline 69 & Keratin 19 & gil1070608 & 5.11 & 44065 & 331 & 78 & $29 / 50$ & Cytoskeleton & Structural \\
\hline 70 & Keratin 19 & gil1070608 & 5.11 & 44065 & 331 & 78 & $29 / 50$ & Cytoskeleton & Structural \\
\hline 71 & $ß$ actin & gil15277503 & 5.55 & 40536 & 119 & 49 & $11 / 30$ & Cytoskeleton & Structural \\
\hline 72 & Keratin 19 & gil6729681 & 5.04 & 44079 & 78 & 18 & $7 / 18$ & Cytoskeleton & Structural \\
\hline 73 & $\beta$ actin & gil15277503 & 5.55 & 40536 & 119 & 49 & $11 / 30$ & Cytoskeleton & Structural \\
\hline 74 & $\beta$ actin & gil15277503 & 5.55 & 40536 & 76 & 37 & $9 / 39$ & Cytoskeleton & Structural \\
\hline 75 & Keratin 19 & gil1070608 & 5.11 & 44079 & 80 & 18 & $7 / 18$ & Cytoskeleton & Structural \\
\hline 76 & Fragment double fibrin & gil28373962 & 5.84 & 38041 & 77 & 22 & $6 / 14$ & Plasma & Other \\
\hline 77 & $\begin{array}{l}\text { Fragment double-D } \\
\text { from human fibrin }\end{array}$ & gil28373962 & 5.84 & 38041 & 376 & 92 & $29 / 59$ & Plasma & Other \\
\hline 78 & $\begin{array}{l}\text { Fragment double-D } \\
\text { from human fibrin }\end{array}$ & gil28373962 & 5.84 & 38081 & 375 & 85 & $28 / 54$ & Plasma & Other \\
\hline 79 & $\begin{array}{l}\text { Fragment double-D } \\
\text { from human fibrin }\end{array}$ & gil28373962 & 5.84 & 38081 & 214 & 62 & $36 / 60$ & Plasma & Other \\
\hline 80 & $\begin{array}{l}\text { Fragment double-D } \\
\text { from human fibrin }\end{array}$ & gil28373962 & 5.84 & 38081 & 121 & 41 & $11 / 32$ & Plasma & Other \\
\hline 81 & Elongation factor $\mathrm{Tu}$ & gil704416 & 7.7 & 49851 & 196 & 60 & $18 / 46$ & Nucleus & Signal \\
\hline 82 & IDH1 & gil49168486 & 6.53 & 46933 & 159 & 46 & $19 / 54$ & Mitochondria & Energy \\
\hline 83 & $\begin{array}{l}\text { Fragment double-D } \\
\text { from human fibrin }\end{array}$ & gil28373962 & 5.84 & 38041 & 219 & 73 & $19 / 42$ & Plasma & Other \\
\hline 84 & Phosphoglycerate kinase 1 & gil4505763 & 8.3 & 44985 & 86 & 32 & $12 / 45$ & Cytoplasm & Signal \\
\hline 85 & $\begin{array}{l}\text { Aldolase A, } \\
\text { fructose-bisphosphatase }\end{array}$ & gil4557305 & 8.49 & 39720 & 117 & 44 & $13 / 43$ & Cytoplasm & Energy \\
\hline 86 & $\begin{array}{l}\text { Glyceraldehyde- } \\
\text { 3-phosphate dehydrogenase }\end{array}$ & gil32891805 & 8.26 & 36202 & 84 & 45 & $10 / 46$ & Cytoplasm & Energy \\
\hline 87 & $\begin{array}{l}\text { Glyceraldehyde- } \\
\text { 3-phosphate dehydrogenase }\end{array}$ & gil32891805 & 8.58 & 36070 & 90 & 47 & $10 / 40$ & Cytoplasm & Energy \\
\hline
\end{tabular}


Table I. Continued

\begin{tabular}{|c|c|c|c|c|c|c|c|c|c|}
\hline $\begin{array}{l}\text { Spot } \\
\text { ID }\end{array}$ & Protein name & $\mathrm{AC}$ & $\mathrm{pI}$ & MW & Score & $\begin{array}{l}\text { Coverage } \\
(\%)\end{array}$ & $\mathrm{M} / \mathrm{Q}$ & Localization & Function \\
\hline 88 & $\begin{array}{l}\text { Glyceraldehyde } \\
\text { 3-phosphate dehydrogenase }\end{array}$ & gil32891805 & 8.58 & 36070 & 90 & 47 & $10 / 39$ & Cytoplasm & Energy \\
\hline 89 & HNRPA2B1 protein & gil32880197 & 8.97 & 37464 & 164 & 44 & $13 / 25$ & Nucleus & Signal \\
\hline 90 & HNRPA2B1 protein & gil14043072 & 8.97 & 37464 & 162 & 44 & $13 / 26$ & Nucleus & Signal \\
\hline 91 & B tropomyosin & gil6573280 & 4.7 & 29980 & 84 & 29 & $11 / 35$ & Cytoskeleton & Structural \\
\hline 92 & $\beta$ tropomyosin & gil6573280 & 4.7 & 29980 & 84 & 29 & $11 / 35$ & Cytoskeleton & Structural \\
\hline 93 & Fibrin $\alpha \mathrm{N}$ term fragment & gil223068 & 9.08 & 26564 & 134 & 53 & $13 / 31$ & Plasma & Other \\
\hline 94 & $\begin{array}{l}\text { Eukaryotic translation } \\
\text { elongation factor } 1 \text { B } 2\end{array}$ & gil30582997 & 4.5 & 24919 & 104 & 44 & $7 / 12$ & Nucleus & Signal \\
\hline 95 & Tropomyosin 3 & gil55665780 & 4.77 & 27386 & 160 & 43 & $17 / 77$ & Cytoskeleton & Structural \\
\hline 96 & Tropomyosin 3 & gil55665780 & 4.77 & 27386 & 160 & 43 & $17 / 44$ & Cytoskeleton & Structural \\
\hline 97 & Tropomyosin 3 & gil55665780 & 4.77 & 27386 & 160 & 43 & $17 / 44$ & Cytoskeleton & Structural \\
\hline 98 & Chloride intracellular channel 1 & gil55961618 & 5.09 & 27248 & 152 & 58 & $12 / 32$ & Mitochondria & Channel \\
\hline 99 & $\alpha$ tubulin & gil37492 & 5.02 & 50810 & 82 & 26 & $8 / 20$ & Cytoskeleton & Structural \\
\hline 100 & $\begin{array}{l}\text { F-actin capping protein } \\
\alpha-1 \text { subunit }\end{array}$ & gil5453597 & 5.45 & 33073 & 103 & 41 & $7 / 11$ & Cytoskeleton & Structural \\
\hline 101 & $\begin{array}{l}\text { GTP-binding regulatory } \\
\text { protein } \beta-2 \text { chain }\end{array}$ & GBB2_HUMAN & 5.6 & 38048 & 66 & 22 & $8 / 36$ & $\begin{array}{l}\text { Several } \\
\text { compartments }\end{array}$ & Signal \\
\hline 102 & Inorganic pyrophosphatase & gil33150672 & 5.54 & 33095 & 147 & 64 & $12 / 29$ & Cytoplasm & Metabolism \\
\hline 103 & Annexin A3 & gil4826643 & 5.63 & 36524 & 131 & 40 & $11 / 21$ & Membrane & Signal \\
\hline 104 & $\begin{array}{l}\text { Proteasome activator } \\
\text { subunit } 2\end{array}$ & gil48734793 & 5.44 & 27515 & 64 & 27 & $5 / 14$ & Cytoplasm & Protein process \\
\hline 105 & Lactate dehydrogenase B & gil54696396 & 5.72 & 36769 & 134 & 51 & $15 / 55$ & Cytoplasm & Energy \\
\hline 106 & Pyruvate kinase & gil35505 & 7.58 & 58411 & 92 & 31 & $11 / 34$ & Cytoplasm & Energy \\
\hline 107 & Protein PP4-X & gil189617 & 5.65 & 36232 & 173 & 39 & $12 / 17$ & Membrane & Signal \\
\hline 108 & PSME1 & gil49456277 & 5.78 & 28862 & 84 & 41 & $11 / 41$ & Cytoplasm & $\begin{array}{l}\text { Cell death/ } \\
\text { defense }\end{array}$ \\
\hline 109 & $\begin{array}{l}\text { Pyruvate dehydrogenase } \\
\text { ß subunit precursor }\end{array}$ & gil189754 & 6.2 & 39566 & 80 & 43 & $10 / 47$ & Cytoplasm & Energy \\
\hline 110 & Annexin A1 & gil4502101 & 6.57 & 38918 & 165 & 55 & $16 / 41$ & Membrane & Signal \\
\hline 111 & PDZ and LIM domain 1 & gil13994151 & 6.8 & 36604 & 73 & 41 & $7 / 29$ & Cytoskeleton & Channel \\
\hline 112 & Alcohol dehydrogenase & gil1633300 & 6.34 & 36761 & 143 & 45 & 11 & Cytoplasm & Metabolism \\
\hline 113 & Fragment $\mathrm{D}$ of fibrinogen & gil49258705 & 7.66 & 36287 & 156 & 46 & $13 / 25$ & Plasma & Other \\
\hline 114 & $\begin{array}{l}\text { Glyceraldehyde- } \\
\text { 3-phosphate dehydrogenase }\end{array}$ & gil32891805 & 8.26 & 36201 & 126 & 51 & $13 / 43$ & Cytoplasm & Metabolism \\
\hline 115 & $\begin{array}{l}\text { Glyceraldehyde- } \\
\text { 3-phosphate dehydrogenase }\end{array}$ & gil32891805 & 8.26 & 36201 & 87 & 46 & $10 / 42$ & Cytoplasm & Metabolism \\
\hline 116 & VDAC2 protein & gil15277577 & 6.81 & 30849 & 91 & 49 & $10 / 45$ & Membrane & Channel \\
\hline 117 & $\begin{array}{l}\text { Guanine nucleotide } \\
\text { binding protein }\end{array}$ & gil21619296 & 7.6 & 35511 & 75 & 27 & $6 / 19$ & Cytoplasm & Signal \\
\hline 118 & Prohibitin & gil46360168 & 5.57 & 29859 & 166 & 69 & $15 / 47$ & Cytoplasm & Signal \\
\hline 119 & $\begin{array}{l}\text { Proteasome } \\
\text { activator subunit } 1\end{array}$ & gil54695544 & 5.78 & 28876 & 96 & 45 & $12 / 41$ & $\begin{array}{l}\text { Several } \\
\text { compartments }\end{array}$ & Protein process \\
\hline 120 & 6-phosphogluconolactonase & gil6018458 & 5.7 & 27815 & 63 & 30 & $6 / 29$ & Cytoplasm & Energy \\
\hline 121 & Glutathione transferase $\omega$ 1-1 & gil55925946 & 6.23 & 27833 & 99 & 28 & $7 / 11$ & Cytoplasm & $\begin{array}{l}\text { Cell death/ } \\
\text { defence }\end{array}$ \\
\hline 122 & $\begin{array}{l}\text { Endoplasmic reticulum } \\
\text { protein } 29 \text { precursor }\end{array}$ & gil5803013 & 6.77 & 29032 & 75 & 26 & $6 / 13$ & ER & Protein process \\
\hline 123 & Macropain subunit ı & gil296736 & 5.58 & 25078 & 80 & 56 & $12 / 36$ & $\begin{array}{l}\text { Several } \\
\text { compartments }\end{array}$ & Metabolism \\
\hline 124 & IgG $\kappa$ light chain & BAC01688 & 6.15 & 28989 & 66 & 40 & $7 / 17$ & Plasma & Other \\
\hline 125 & PRO2044 & gil6650826 & 6.97 & 30084 & 161 & 56 & $12 / 20$ & Plasma & Unknown \\
\hline 126 & $\begin{array}{l}\text { Proteasome endopeptidase } \\
\text { complex } \xi \text { chain }\end{array}$ & gil88168 & 4.74 & 26579 & 82 & 48 & $8 / 39$ & $\begin{array}{l}\text { Several } \\
\text { compartments }\end{array}$ & Metabolism \\
\hline 127 & rho GDP dissociation inhibitor $\alpha$ & gil30582607 & 5.02 & 23250 & 79 & 42 & $8 / 16$ & Cytoplasm & Signal \\
\hline
\end{tabular}


Table I. Continued.

\begin{tabular}{|c|c|c|c|c|c|c|c|c|c|}
\hline $\begin{array}{l}\text { Spot } \\
\text { ID }\end{array}$ & Protein name & $\mathrm{AC}$ & $\mathrm{pI}$ & MW & Score & $\begin{array}{l}\text { Coverage } \\
(\%)\end{array}$ & M/Q & Localization & Function \\
\hline 128 & rho GDP dissociation inhibitor $\beta$ & gil20379030 & 5.1 & 23030 & 88 & 69 & $12 / 41$ & Cytoplasm & Signal \\
\hline 129 & $\gamma$ actin & gil40226101 & 5.5 & 29687 & 92 & 55 & $9 / 21$ & Cytoskeleton & Structural \\
\hline 130 & Heat shock protein 27 & gil662841 & 7.83 & 22313 & 76 & 28 & $6 / 19$ & Cytoplasm & Cell death/defense \\
\hline 131 & Thioredoxin peroxidase & gil5453549 & 5.86 & 30749 & 88 & 54 & $10 / 28$ & Cytoplasm & Signal \\
\hline 132 & GRB2 & gil47496673 & 6.08 & 25246 & 121 & 45 & $9 / 16$ & Nucleus & Signal \\
\hline 133 & Heat shock $27 \mathrm{kDa}$ protein 1 & gil54696638 & 5.98 & 22826 & 124 & 56 & $14 / 69$ & Cytoplasm & Cell death/defense \\
\hline 134 & Serum albumin & gil37222202 & 5.25 & 19788 & 117 & 68 & $11 / 46$ & Plasma & Other \\
\hline 135 & Peroxiredoxin 6 & gil56204402 & 6 & 25133 & 82 & 45 & $8 / 30$ & Cytoplasm & Cell death/defense \\
\hline 136 & Triosephosphate isomerase & gil999893 & 6.51 & 26807 & 69 & 48 & $10 / 35$ & Cytoplasm & Energy \\
\hline 137 & Triosephosphate isomerase & gil999893 & 6.51 & 26807 & 125 & 68 & $15 / 38$ & Cytoplasm & Energy \\
\hline 138 & Triosephosphate isomerase & gil999893 & 6.51 & 26087 & 98 & 70 & $15 / 61$ & Cytoplasm & Energy \\
\hline 139 & Triosephosphate isomerase & gil999893 & 6.51 & 26807 & 101 & 72 & $16 / 61$ & Cytoplasm & Energy \\
\hline 140 & Triosephosphate isomerase & gil999893 & 6.51 & 26807 & 119 & 75 & $17 / 55$ & Cytoplasm & Energy \\
\hline 141 & HES1 & gil1655594 & 8.5 & 28485 & 88 & 47 & $8 / 15$ & Nucleus & Signal \\
\hline 142 & Triosephosphate isomerase & gil999893 & 6.51 & 26807 & 73 & 72 & $16 / 92$ & Cytoplasm & Energy \\
\hline 143 & $\begin{array}{l}\text { Glyceraldehyde 3-phosphate } \\
\text { dehydrogenase }\end{array}$ & G3P2_HUMAN & 8.58 & 36070 & 64 & 25 & $5 / 15$ & Cytoplasm & Energy \\
\hline 144 & Peroxiredoxin 1 & gil55959887 & 6.41 & 19135 & 104 & 53 & $7 / 16$ & Cytoplasm & Cell death/defense \\
\hline 145 & Flavin reductase & gil32891807 & 7.13 & 22219 & 102 & 64 & $7 / 18$ & Cytoplasm & Metabolism \\
\hline 146 & Neuropolypeptide h3 & gil913159 & 7.42 & 21027 & 116 & 62 & $10 / 18$ & Cytoplasm & Signal \\
\hline 147 & Peroxiredoxin 1 & gil55959887 & 8.58 & 19135 & 130 & 61 & $9 / 19$ & Cytoplasm & Cell death/defense \\
\hline 148 & FGA protein & gil47124990 & 8.57 & 33426 & 72 & 33 & $9 / 34$ & Unknown & Unknown \\
\hline 149 & FGA protein & gil47124990 & 8.57 & 33426 & 94 & 39 & $13 / 44$ & Unknown & Unknown \\
\hline 150 & ALB protein & gil27692693 & 5.97 & 48641 & 102 & 24 & $9 / 21$ & Plasma & Other \\
\hline 151 & Proteasome $\beta$ subunit & gil56207312 & 4.92 & 22428 & 75 & 39 & $7 / 27$ & $\begin{array}{l}\text { Several } \\
\text { compartments }\end{array}$ & Protein process \\
\hline 152 & ALB protein & gil27692693 & 5.97 & 48641 & 114 & 25 & $10 / 20$ & Plasma & Other \\
\hline 153 & Glyoxalase I & gil15030212 & 5.12 & 20955 & 122 & 61 & $9 / 23$ & Cytoplasm & Metabolism \\
\hline 154 & Proapolipoprotein & gil178775 & 5.45 & 28944 & 227 & 71 & $19 / 37$ & Plasma & Transport \\
\hline 155 & Apolipoprotein A1 & gil37499465 & 5.56 & 30759 & 188 & 66 & $20 / 55$ & Plasma & Transport \\
\hline 156 & ATP synthase D chain & gil5453559 & 5.21 & 18537 & 95 & 68 & $10 / 47$ & Mitochondria & Energy \\
\hline 157 & ALB protein & gil37222202 & 5.25 & 19788 & 169 & 76 & $14 / 43$ & Plasma & Other \\
\hline 158 & Glutathione transferase & gil2204207 & 5.43 & 23595 & 119 & 60 & $11 / 42$ & Cytoplasm & Cell death/defense \\
\hline 159 & Peroxiredoxin 2 & gil61362999 & 5.66 & 22048 & 70 & 28 & $7 / 30$ & Cytoplasm & Cell death/defense \\
\hline 160 & Glutathione peroxidase & gil577062 & 6.15 & 22193 & 85 & 37 & $6 / 15$ & Cytoplasm & Cell death/defense \\
\hline 161 & Peroxiredoxin 3 & ААН02685 & 7.67 & 28017 & 88 & 54 & $8 / 30$ & Cytoplasm & Cell death/defense \\
\hline 162 & $\begin{array}{l}\text { Rhoa Complexed } \\
\text { with Gtp Analogue }\end{array}$ & gil3318980 & 5.07 & 20842 & 87 & 46 & $6 / 14$ & Cytoplasm & Signal \\
\hline 163 & $\begin{array}{l}\text { RNA-binding protein } \\
\text { regulatory subunit }\end{array}$ & AAC1208 & 6.33 & 20050 & 168 & 86 & $15 / 60$ & ER & Signal \\
\hline 164 & cdc42hs-Gdp Complex chain B & gil4389380 & 5.78 & 21434 & 147 & 65 & $10 / 23$ & Nucleus & Signal \\
\hline 165 & $\begin{array}{l}\text { Proteasome endopeptidase } \\
\text { complex B chain }\end{array}$ & S55040 & 6.51 & 22993 & 79 & 26 & $6 / 8$ & $\begin{array}{l}\text { Several } \\
\text { compartments }\end{array}$ & Protein process \\
\hline 166 & MN-Superoxiddismutase & CAA01016 & 7.96 & 19945 & 111 & 58 & $10 / 20$ & Cytoplasm & Cell death/defense \\
\hline 167 & Calmodulin 2 & gil14250065 & 4.1 & 16826 & 76 & 56 & $9 / 60$ & Cytoplasm & Signal \\
\hline 168 & Myosin light chain 3 & gil188590 & 4.42 & 17091 & 64 & 28 & $5 / 20$ & Cytoskeleton & Structural \\
\hline 169 & Myosin alkali light chain 6 & gil17986264 & 4.51 & 17717 & 88 & 51 & $7 / 33$ & Cytoskeleton & Structural \\
\hline 170 & Myosin alkali light chain 6 & gil17986264 & 4.51 & 17717 & 80 & 51 & $7 / 35$ & Cytoskeleton & Structural \\
\hline 171 & Calmodulin like 5 & AAH39172 & 4.34 & 15881 & 96 & 52 & $5 / 7$ & Cytoplasm & Signal \\
\hline 172 & $\begin{array}{l}\text { Almodulin related- } \\
\text { protein NB-1 }\end{array}$ & CALL_HUMAN & 4.3 & 16806 & 91 & 47 & $5 / 7$ & Cytoplasm & Signal \\
\hline 173 & Sorcin & S5209 & 5.32 & 21947 & 78 & 41 & $8 / 41$ & Cytoplasm & Unknown \\
\hline 174 & PACAP protein & gil18204192 & 5.37 & 21023 & 78 & 57 & $7 / 31$ & Unknown & Unknown \\
\hline
\end{tabular}


Table I. Continued

\begin{tabular}{|c|c|c|c|c|c|c|c|c|c|}
\hline $\begin{array}{l}\text { Spot } \\
\text { ID }\end{array}$ & Protein name & $\mathrm{AC}$ & $\mathrm{pI}$ & MW & Score & $\begin{array}{l}\text { Coverage } \\
(\%)\end{array}$ & $\mathrm{M} / \mathrm{Q}$ & Localization & Function \\
\hline 175 & Haptoglobin $\alpha$ and $\beta$-chain & CAA25248 & 6.25 & 42126 & 84 & 22 & $8 / 23$ & Plasma & Transport \\
\hline 176 & $\begin{array}{l}\text { Nucleoside-diphosphate } \\
\text { kinase } \mathrm{nm} 23-\mathrm{H} 1 \mathrm{~g}\end{array}$ & A33386 & 5.83 & 17309 & 88 & 51 & $7 / 25$ & Nucleus & Structural \\
\hline 177 & $\begin{array}{l}\text { Ras-related } \\
\text { protein rap-1a rap, chain A }\end{array}$ & A34655 & 5.65 & 21040 & 84 & 35 & $7 / 17$ & Cytoplasm & Signal \\
\hline 178 & Haptoglobin $\alpha$ and $\beta$ chain & CAA25248 & 6.25 & 42126 & 68 & 62 & $8 / 34$ & Plasma & Transport \\
\hline 179 & Superoxide dismutase & CAE99479 & 5.7 & 16023 & 73 & 64 & $7 / 35$ & Cytoplasm & Cell death/defense \\
\hline 180 & Haptoglobin $\alpha$ and $\beta$ chain & CAA25248 & 6.25 & 42126 & 81 & 20 & $7 / 19$ & Plasma & Transport \\
\hline 181 & LMW-PTP & PPAC_HUMAN & 6.35 & 18356 & 148 & 74 & $10 / 21$ & Cytoplasm & Signal \\
\hline 182 & Transthyretin, chain A & 2ROXA & 5.33 & 12939 & 182 & 86 & $10 / 20$ & Nucleus & Signal \\
\hline 183 & AIF-1 & Q9UKS9 & 6.63 & 16792 & 100 & 57 & $7 / 16$ & Nucleus & Signal \\
\hline 184 & Ubiquitin-protein ligase & JC4894 & 6.13 & 17127 & 77 & 42 & $6 / 21$ & Extracellular & Signal \\
\hline 185 & Cyclophilin A & PPIA_HUMAN & 7.68 & 17870 & 102 & 35 & $7 / 17$ & Cytoplasm & Structural \\
\hline 186 & Peroxiredoxin 5 & gil46015020 & 7.94 & 18327 & 146 & 69 & $11 / 34$ & Cytoplasm & Cell death/defense \\
\hline 187 & Cyclophilin A & PPIA_HUMAN & 7.82 & 18098 & 77 & 54 & $9 / 53$ & Cytoplasm & Structural \\
\hline 188 & Cyclophilin A & AAH07104 & 7.82 & 18228 & 87 & 66 & $11 / 63$ & Cytoplasm & Structural \\
\hline 189 & Cofilin & P23528 & 8.22 & 18371 & 147 & 67 & $12 / 33$ & Cytoskeleton & Structural \\
\hline 190 & Destrin & $1 \mathrm{AK} 6$ & 8.05 & 19794 & 90 & 36 & $6 / 10$ & Cytoskeleton & Structural \\
\hline 191 & PPIB & gil48145775 & 9.42 & 23771 & 104 & 38 & $7 / 17$ & Cytoplasm & Structural \\
\hline 192 & IgG Fc-Fragment, Chain A & gil28373341 & 7 & 25422 & 75 & 46 & $8 / 21$ & Plasma & Other \\
\hline 193 & IGHG1 protein & gil49522738 & 8.35 & 51757 & 70 & 23 & $8 / 18$ & Plasma & Other \\
\hline 194 & Calgranulin B & gil4506773 & 5.71 & 13291 & 101 & 87 & $7 / 30$ & Cytoplasm & Signal \\
\hline 195 & MRP-14 Protein & CAA00999 & 5.55 & 12770 & 77 & 44 & $5 / 7$ & Cytoplasm & Signal \\
\hline 196 & Calgranulin & B31848 & 5.71 & 13291 & 126 & 81 & $8 / 22$ & Cytoplasm & Signal \\
\hline 197 & MRP-14 Protein & CAA00999 & 5.55 & 12770 & 81 & 84 & $8 / 48$ & Cytoplasm & Signal \\
\hline 198 & $\begin{array}{l}\text { Serum amyloid A1 } \\
\text { protein precursor }\end{array}$ & gil40316910 & 6.28 & 13581 & 86 & 66 & $7 / 38$ & Plasma & Other \\
\hline 199 & Unknown Protein & AAH14308 & 8 & 23322 & 69 & 34 & $6 / 25$ & Unknown & Unknown \\
\hline 200 & $\operatorname{IgG} \kappa$ chain $\mathrm{c}$ region & A37927 & 5.61 & 11161 & 76 & 58 & $5 / 23$ & Plasma & Other \\
\hline 201 & $\beta 2$ microglobulin & 1HLAM & 6.46 & 11592 & 63 & 52 & $5 / 27$ & Plasma & Other \\
\hline 202 & Calgranulin A & BCHUCF & 6.51 & 10828 & 112 & 76 & $8 / 24$ & $\begin{array}{l}\text { Several } \\
\text { compartments }\end{array}$ & Signal \\
\hline 203 & Unknown Protein & AAH14308 & 8 & 23322 & 78 & 28 & $5 / 13$ & Unknown & Unknown \\
\hline 204 & Hemoglobin $ß$ chain (deoxy) & $1 \mathrm{~A} 3 \mathrm{NB}$ & 6.82 & 15872 & 172 & 91 & $13 / 46$ & Plasma & Transport \\
\hline 205 & Tetraubiquitin Chain B & 1TBEB & 5.73 & 8176 & 74 & 65 & $5 / 25$ & $\begin{array}{l}\text { Several } \\
\text { compartments }\end{array}$ & Protein process \\
\hline 206 & $\begin{array}{l}\text { Hemoglobin } \beta \\
\text { chain (deoxy) }\end{array}$ & $1 \mathrm{~A} 3 \mathrm{NB}$ & 6.82 & 15872 & 163 & 91 & $14 / 70$ & Plasma & Transport \\
\hline 207 & PRO2675 & AAF69644 & 6.14 & 33466 & 65 & 22 & $6 / 17$ & Plasma & Unknown \\
\hline 208 & Cytoplasmic actin & CAA23745 & 7.85 & 14207 & 68 & 70 & $6 / 37$ & Cytoplasm & Structural \\
\hline 209 & Hemoglobin $\delta$ chain & HDHU & 7.97 & 16028 & 163 & 91 & $13 / 46$ & Plasma & Transport \\
\hline 210 & PRO2675 & AAF69644 & 6.14 & 33466 & 68 & 22 & $6 / 15$ & Plasma & Unknown \\
\hline 211 & Hemoglobin $\delta$ chain & HDHU & 7.97 & 16028 & 86 & 71 & $9 / 63$ & Plasma & Transport \\
\hline 212 & Hemoglobin $\alpha$ chain & 1DSHA & 8.07 & 15018 & 76 & 56 & $6 / 29$ & Plasma & Transport \\
\hline 213 & Profilin, chain A & 1AWIA & 8.46 & 15014 & 137 & 24 & $10 / 37$ & Cytoskeleton & Structural \\
\hline 214 & Hemoglobin $\delta$ chain & HDHU & 7.97 & 16028 & 99 & 75 & $10 / 58$ & Plasma & Transport \\
\hline 215 & Lysozyme & $134 \mathrm{~L}$ & 9 & 15120 & 102 & 76 & $10 / 53$ & Cytoplasm & Cell death/defense \\
\hline 216 & $\alpha 2$ globin & gil1335076 & 8.73 & 15174 & 115 & 93 & $10 / 43$ & Plasma & Transport \\
\hline
\end{tabular}

ER, endoplasmic reticulum.

our website http://www.xyproteomics.org/en/. SpotID represented the protein spot ID on the gel, protein name or
$\mathrm{AC}$ number represented protein name or $\mathrm{AC}$ number in MSDB or NCBInr database. Theoretical pI, theoretical Mw, 
A

B

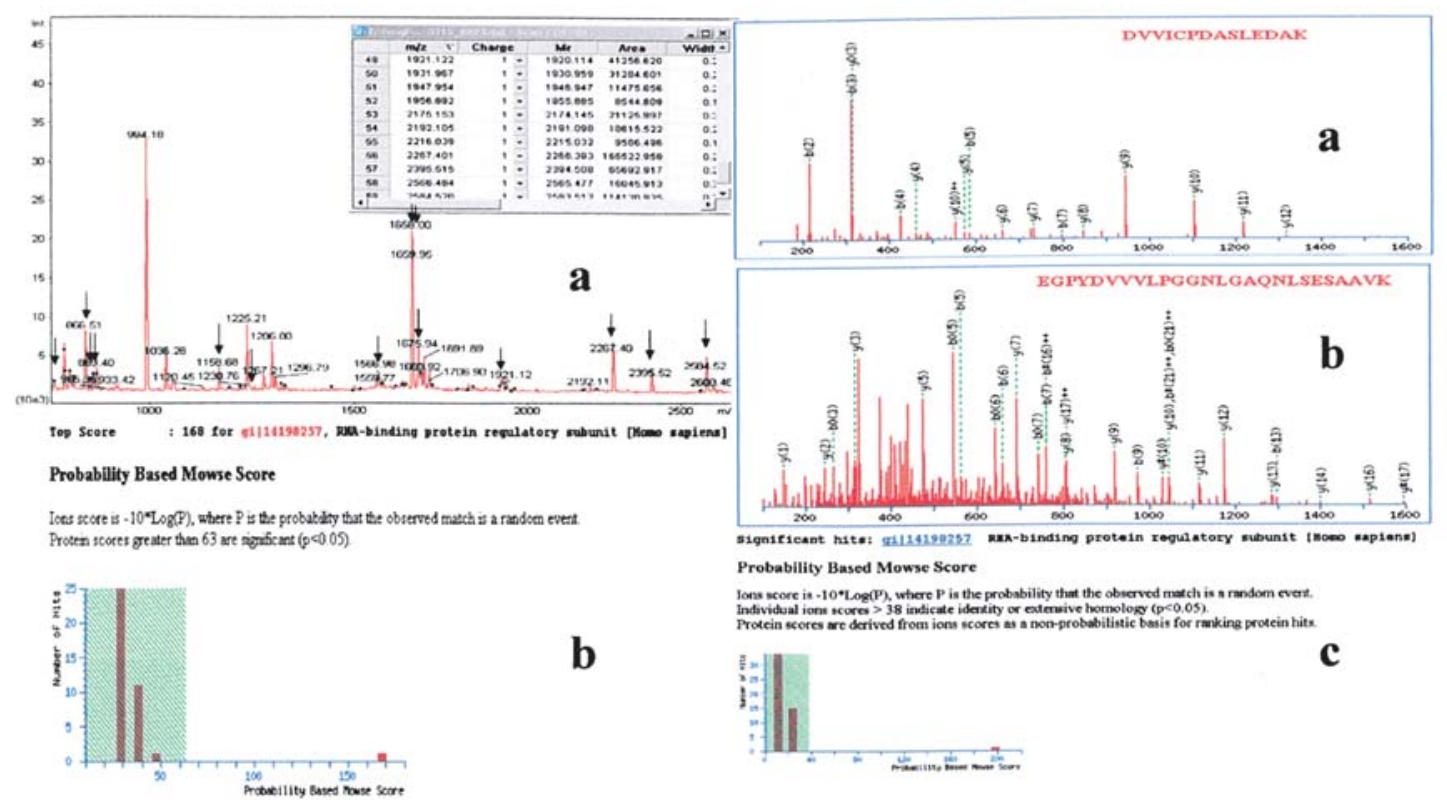

1 MASKRALVIL AKGAEEIETV IPVDVIRRAG INVTVAGLAG KDPVQQCSRDV 51 VICPDASLED AKKEGPYDV VLPGGILGA IILSESAAVKE ILKEOQEIRKG 101 LIAAICAGPT ALLANEIGFG SKVTTHPLAK DHEDIGGHT YSEIRVVEKG 151 LILTSRGPGT SFEFALATVE ALIIGKEVAגQ VRAPLULKD

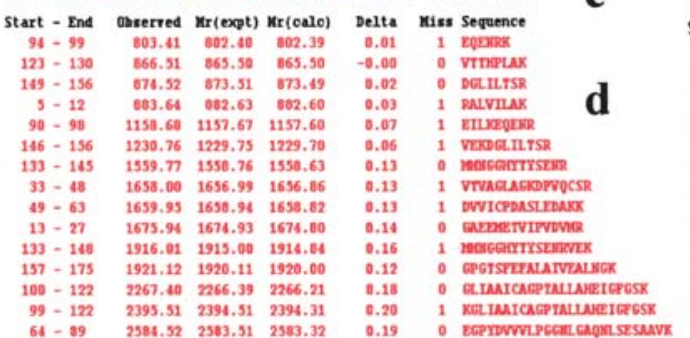

1 MASKRALVTL AKGAEEMETV IPVDUMRRAG IKVTVAGLAG KDPVOCSRDV 51 VICPDASLED AKKEGPYDVV VLPGGILGAO ILLSESAAVKE ILXEQENRKG 101 LIAMICAGPT ALLAHEIGFG SKVTTHPLAK DKMIDGGHYT YSENRVEKDG 151 LILTSRGPG SFEFLAIVE ALHGKEVAR VRAPLULKD d

\begin{tabular}{|c|c|c|c|c|c|c|}
\hline & serred & Ir $r$ empt & $\mathbf{M r}($ calc $)$ & Delta & Hiss Sequence & \\
\hline $33-41$ & 408.27 & 814.52 & 81.69 & 0.03 & 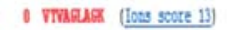 & \\
\hline $33-41$ & 468.27 & 14. 52 & 014.69 & 0.03 & 0 maghar (teas soote 21) & \\
\hline $169-15$ & 437. $n$ & 873.52 & 873.19 & 0.03 & 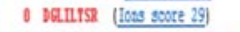 & $\theta$ \\
\hline $19-6$ & 766.38 & 1530.74 & 1530.72 & 0.01 & o wiophasuar ligens soore ? & \\
\hline-6. & 38 & 1530.74 & $1530 . n$ & 0.02 & - owichusuar tions sote ? & \\
\hline-62 & 765.38 & 1530.74 & $1530 . n$ & 0.02 & 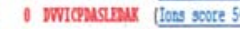 & \\
\hline-99 & 2.11 & 2583.31 & 2583.32 & -0.00 & 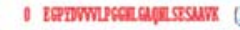 & Tens \\
\hline-89 & 862.13 & 2583.36 & 2583.32 & 0.14 & 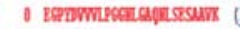 & Ions score: \\
\hline $4-8$ & 862.13 & 2583.36 & 283.32 & 0.05 & 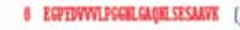 & tas scose ? \\
\hline-6 & 1292.71 & 2583.41 & 3.32 & 0.09 & 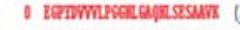 & 98000 \\
\hline-19 & 292.4 & 2583.46 & 2503.32 & 0.14 & 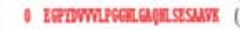 & \\
\hline
\end{tabular}

Figure 3. MALDI-TOF, Q-TOF mass spectrometry map and database query result of spot 135. (A) MALDI-TOF mass spectrometry map and database query result of spot 135. a, Monoisotopic peaks of MALDI-TOF mass spectrometry map, arrays showed the matched monoisotopic peak; b, database query result and scores; c, protein sequence and coverage sequence; d, matched peptide fragment and error between experimental mass and theoretical mass. (B) MS/MS analysis and database query result of the spot 135 . a, A peptide that contains 14 amino acids; b, a peptide that contains 26 amino acids; c, database query result and its scores; d, protein sequence and its coverage sequence; e, matched peptide fragment and its sequence.

Sequence Coverage and scores of database querying are also provided. Furthermore, the number of matched query and number of input monoisotopic peaks are provided in Table I.

A representative MALDI-TOF mass spectrometry map and database query result are shown in Fig. 3A. A total of 60 monoisotopic peaks were input into MASCOT PMF database search program (http://www.matrixscience.com/cgi/search form.pl?FORMVER $=2 \&$ SEARCH $=$ PMF). The matched peptide fragment number is 15 , the database query score is 168 and the query result shows that protein is RNA-binding protein regulatory subunit. The sequence of matched peptide fragment, start-end position and the error between theoretical peptide mass and experimental peptide mass are also shown in Fig. 3A. Illustrated as this example, a high quality of PMF mapping is an essential fundament to successfully query databases. With the high quality of peptide mass fingerprint mapping, a default setting can be used to process the PMF map to get the monoisotopic peak lists without filtering the contaminated peak lists. On the other hand, it can be more easy to attain an unambiguous result with a probability based algorithm such as MASCOT than using software based simply on scoring algorithm (20). The MS/MS results of the same spot are shown in Fig. 3B, an 8-amino acid peptide and a 26amino acid peptide were sequenced. Although the sequence coverage of the tandem mass spectrometry identified peptide fragments is lower than that acquired by MALDI-TOF mass spectrometry, the score of the tandem mass spectrometry identified result is higher than the score of PMF. Part of the coverage sequence identified by both two kinds of mass spectrometry is identical, which illuminate that the identified result is unambiguous.

Subcellular localization and functional groups of the identified proteins. The 216 identified proteins of NPC have been classified in terms of their subcellular localization (Fig. 4A) and physiological function (Fig. 4B) using information from SWISS-PROT and NCBI websites. The majority of identified proteins of NPC (Fig. 4A) are localized in the cytoplasm $(34 \%)$, cytoskeleton $(14 \%)$ or several major cellular compartments such as nucleus $(6 \%)$ and endoplasmic reticulum (ER, 4\%) or several compartments (4\%). Only $4 \%$ of these proteins were membrane proteins and $3 \%$ 


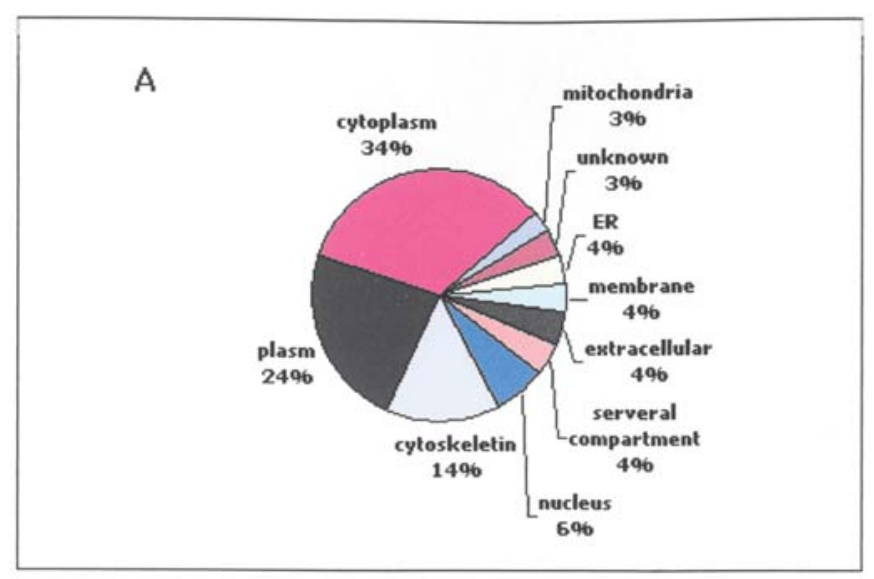

B

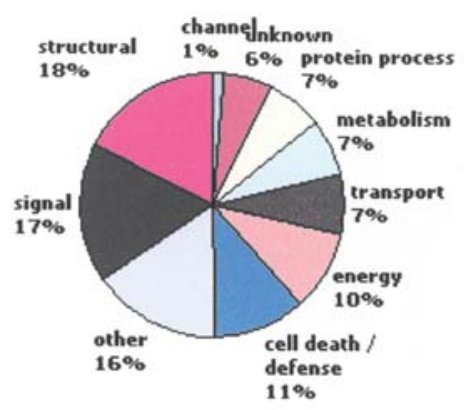

Figure 4. Pie charts representing (A) the distribution of the identified 201 proteins in NPC proteome according to their cellular localization and (B) the distribution of the 201 identified proteins in NPC proteome according to their biological function. Assignments were made on the basis of information provided on the NCBI or ExPASy websites. ER, endoplasmic reticulum.

mitochondria, which shows membrane proteins need more stringent protocol to be extracted. Moreover, a relative part of identified proteins were extracellular proteins $(4 \%)$, such as vimentin that was identified in secretome. Among them, 24\% identified proteins were plasma proteins, and 27 protein spots were identified as hemoglobin and fibrinogen or their isoforms, which indicates that the use of more pure nasopharyngeal carcinoma tissue would help to decrease the contamination from blood.

A large group of the identified proteins are subcellular defense proteins $(11 \%)$, such as peroxiredoxin $1,2,3,5,6$, the different isoforms of peroxiredoxin, which are involved in redox regulation of the cellular function and are associated with various biological processes, such as the detoxification of oxidants, cell proliferation, cell differentiation and gene expression (21). Heat shock proteins 27, 70, 9B precursor are also in this class, which are produced at a high level by cells to protect themselves against unfavorable conditions. Seven percent of the proteins identified are metabolic enzymes such as triosephosphate isomerase, glyceraldehyde-3-phosphate dehydrogenase, $\alpha$ enolase, etc., which are involved in several metabolic pathways. These metabolic enzymes were also found in other expression proteome studies, which showed they were housekeeping proteins $(22,23)$. Structural proteins are a large part of the identified proteins (18\%), for example, actin, tubulin, and keratin. Several actin related proteins were also identified such as profilin, destrin and F-actin capping protein $\alpha-1$ subunit. Some of these actin-binding proteins are essential for the reorganization of actin filaments as a cellular response to various growth factors, and which could play crucial roles in human disorders (24). Seventeen percent of the identified proteins are involved in signal transduction proteins, for example, phosphoglycerate kinase 1, calgranulin, and rasrelated protein rap-1a. Several heterogeneous nuclear ribonucleoproteins were also identified as signal transduction proteins, such as heterogeneous nuclear ribonucleoprotein $\mathrm{F}$, H1, L. More detailed information about the function and localization of the identified proteins is showed in Table I.

In conclusion, in the present study, we constructed a 2-DE reference map of human nasopharyngeal squamous carcinoma, including 216 identified proteins. To our knowledge, this is the first 2-DE reference map of human NPC. This reference map will serve as a basis for further studies of NPC, especially the proteomic comparison among different cell types of NPC, different differentiated degrees of NPC, different stages in the process of NPC, or between the NPC tissue and normal nasopharyngeal epithelial tissue. The reference map data will be used to expand the proteome database of the human NPC, which can be accessed on our website (http://www.xyproteomics.org/en). Furthermore, the mapping data also provide basic data for integrating the genomic, transcriptomic and proteomic research results to reveal the molecular mechanism of NPC and to screen tumorrelated markers.

\section{Acknowledgments}

This study was supported by a grant from National 973 Project of China (2001CB510208), for Outstanding Scholars of New Era from Ministry of Education of China (2002-48), National Natural Science Foundation of China (30000028, 30240056, 30370642), and key research program from Science and Technology Committee of Hunan, P.R. China (02SSY2001-1), and key research program from Public Health Bureau of Hunan Province, P.R. China (Z02-04).

\section{References}

1. Yu MC and Yuan JM: Epidemiology of nasopharyngeal carcinoma. Semin Cancer Biol 12: 421-429, 2002.

2. Licitra L, Bernier J, Cvitkovic E, Grandi C, Spinazze S, Bruzzi P, Gatta G and Molinari R: Cancer of the nasopharynx. Crit Rev Oncol Hematol 45: 199-213, 2003

3. Huang T, Liu Q, Huang H and Cao S: Study on genetic epidemiology of nasopharyngeal carcinoma in Guangdong, China. Zhonghua Yi Xue Yi Chuan Xue Za Zhi 19: 134-137, 2002.

4. Lo KW and Huang DP: Genetic and epigenetic changes in nasopharyngeal carcinoma. Semin Cancer Biol 12: 451-462, 2002.

5. Cheng Y, Poulos NE, Lung ML, Hampton G, Ou B, Lerman MI and Stanbridge EJ: Functional evidence for a nasopharyngeal carcinoma tumor suppressor gene that maps at chromosome 3p21.3. Proc Natl Acad Sci USA 95: 3042-3047, 1998.

6. Chow LS, Lo KW, Kwong J, To KF, Tsang KS, Lam CW, Dammann R and Huang DP: RASSF1A is a target tumor suppressor from $3 \mathrm{p} 21.3$ in nasopharyngeal carcinoma. Int $\mathrm{J}$ Cancer 109: 839-847, 2004.

7. Raab-Traub N: Epstein-Barr virus in the pathogenesis of NPC. Semin Cancer Biol 12: 431-441, 2002.

8. Griffin BE: Epstein-Barr virus (EBV) and human disease: facts, opinions and problems. Mutat Res 462: 395-405, 2000. 
9. Young LS and Murray PG: Epstein-Barr virus and oncogenesis: from latent genes to tumours. Oncogene 22: 5108-5121, 2003.

10. Baak JP, Path FR, Hermsen MA, Meijer G, Schmidt J and Janssen EA: Genomics and proteomics in cancer. Eur J Cancer 39: 1199-1215, 2003.

11. Hanash SM, Bobek MP, Rickman DS, Williams T, Rouillard JM, Kuick R and Puravs E: Integrating cancer genomics and proteomics in the post-genome era. Proteomics 2: 69-75, 2002.

12. Hanash SM: Global profiling of gene expression in cancer using genomics and proteomics. Curr Opin Mol Ther 3: 538-545, 2001.

13. Sanchez JC, Appel RD, Golaz O, Pasquali C, Ravier F, Bairoch A and Hochstrasser DF: Inside SWISS-2DPAGE database. Electrophoresis 16: 1131-1151, 1995.

14. Hoogland C, Sanchez JC, Walther D, Baujard V, Baujard O, Tonella L, Hochstrasser DF and Appel RD: Two-dimensional electrophoresis resources available from ExPASy. Electrophoresis 20: 3568-3571, 1999.

15. Li C, Chen Z, Xiao Z, Wu X, Zhan X, Zhang X, Li M, Li J, Feng X, Liang S, Chen P and Xie JY: Comparative proteomics analysis of human lung squamous carcinoma. Biochem Biophys Res Commun 309: 253-260, 2003.

16. Candiano G, Bruschi M, Musante L, Santucci L, Ghiggeri GM, Carnemolla B, Orecchia P, Zardi L and Righetti PG: Blue silver: a very sensitive colloidal Coomassie G-250 staining for proteome analysis. Electrophoresis 25: 1327-1333, 2004.

17. Gorg A, Obermaier C, Boguth G and Weiss W: Recent developments in two-dimensional gel electrophoresis with immobilized $\mathrm{pH}$ gradients: wide $\mathrm{pH}$ gradients up to $\mathrm{pH} 12.0$, longer separation distances and simplified procedures. Electrophoresis 20: 712-717, 1999
18. Corbett JM, Dunn MJ, Posch A and Gorg A: Positional reproducibility of protein spots in two-dimensional polyacrylamide gel electrophoresis using immobilised $\mathrm{pH}$ gradient isoelectric focusing in the first dimension: an interlaboratory comparison. Electrophoresis 15: 1205-1211, 1994.

19. Ferguson RE, Carroll HP, Harris A, Maher ER, Selby PJ and Banks RE: Housekeeping proteins: a preliminary study illustrating some limitations as useful references in protein expression studies. Proteomics 5: 566-571, 2005.

20. Perkins DN, Pappin DJ, Creasy DM and Cottrell JS: Probabilitybased protein identification by searching sequence databases using mass spectrometry data. Electrophoresis 20: 3551-3567, 1999 .

21. Kinnula VL, Paakko P and Soini Y: Antioxidant enzymes and redox regulating thiol proteins in malignancies of human lung. FEBS Lett 569: 1-6, 2004.

22. Zhan X and Desiderio DM: A reference map of a human pituitary adenoma proteome. Proteomics 3: 699-713, 2003.

23. Dupont A, Tokarski C, Dekeyzer O, Guihot AL, Amouyel P, Rolando $\mathrm{C}$ and Pinet F: Two-dimensional maps and databases of the human macrophage proteome and secretome. Proteomics 4: 1761-1778, 2004

24. Dos Remedios CG, Chhabra D, Kekic M, Dedova IV, Tsubakihara M, Berry DA and Nosworthy NJ: Actin binding proteins: regulation of cytoskeletal microfilaments. Physiol Rev 83: 433-473, 2003. 